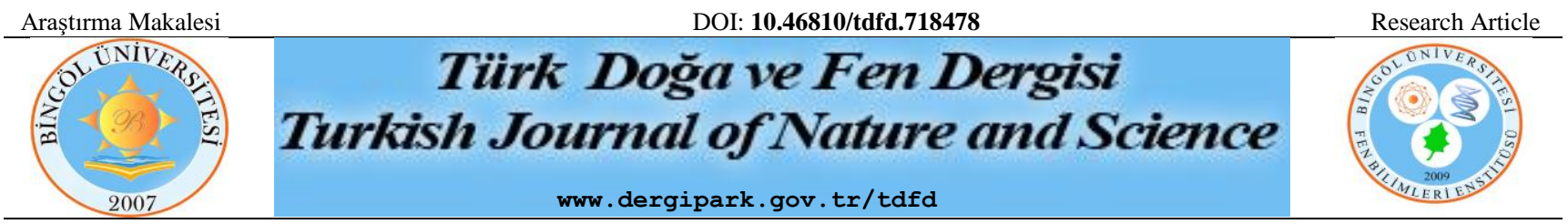

\title{
Yemlik Bezelye ve Yemlik Bakla Bitki Kısımlarının Kalite Özellikleri ve Mineral Madde İçeriklerinin Belirlenmesi
}

\author{
Ömer Süha USLU', Fatma AKBAY ${ }^{2 *}$, Adem EROL ${ }^{3}$ \\ ${ }^{12}$ Kahramanmaraş Sütçü İmam Üniversitesi, Ziraat Fakültesi, Tarla Bitkileri Bölümü, Kahramanmaraş, Türkiye \\ Ömer Suha USLU ORCID No: 0000-0003-0858-0305 \\ Fatma AKBAY ORCID No: 0000- 0002-0156-9974 \\ Adem EROL ORCID No: 0000-0002-3381-8402
}

*Sorumlu yazar: ftm.akbay01@gmail.com

(Alınış: 11.04.2020, Kabul: 31.05.2020, Online Yayınlanma: 18.06.2020)

\begin{abstract}
Anahtar
Kelimeler

Bitki

kisımları,

Ham protein,

Ham kül,

Makro-mikro

element,

Yemlik

bezelye,

Yemlik bakla

Öz: Araştırma, Kahramanmaraş Sütçü İmam Üniversitesi, Ziraat Fakültesi Araştırma ve Uygulama Alanında yetiştirilen yemlik bezelye ve yemlik baklaya ait bazı bitki kısımlarının (tüm bitki, yaprak, sap ve dal) kalite özellikleri ve makro-mikro besin elementi içeriklerini tespit etmek amacıyla yapılmıştır. Çalışma 2017-2018 yetiştirme sezonunda tesadüf bloklarında bölünmüş parseller deneme desenine göre üç tekerrürlü olarak yürütülmüştür. Araştırma sonuçlarına göre; en yüksek kuru madde, ham protein ve ham kül oranı bitkilerin yaprak kısmında saptanmıştır. Kuru madde ve ham protein yönünden yemlik bezelye, kül oranı yönünden bakla bitkisinin zengin olduğu saptanmıştır. Çalışmada $\mathrm{Al}, \mathrm{B}, \mathrm{Ca}, \mathrm{Cd}, \mathrm{Co}, \mathrm{Cr}, \mathrm{Cu}, \mathrm{Fe}, \mathrm{K}, \mathrm{Mg}, \mathrm{Mn}, \mathrm{Na}, \mathrm{Ni}, \mathrm{P}, \mathrm{Pb}$ ve $\mathrm{Zn}$ besin elementleri, türler ve tür x bitki kısımları interaksiyonu arasında önemli derecede fark olduğu saptanmıştır. Tür x bitki kısımları interaksiyonuna ait ortalama değerlerin sırasıyla; 161-251 ppm, 13,1-15,7 ppm, 6019-7681 ppm, 0,01-0,02 ppm, 0,23-0,34 ppm, 1,31-1,69 ppm, 6,99-9,87 ppm, 164-221,9 ppm, 14163-16616 ppm, 2538-3526 ppm, 16,61-27,55 ppm, 2486-6723 ppm, 3,17-8,77 ppm, 2567-3428 ppm, 1,23-1,37 ppm ve 14,31-18,93 ppm arasında değiştiği tespit edilmiştir. Bitkilerin yaprak kısımlarının diğer bitki kısımlarına göre besin elementi yönünden daha zengin ve besleyici olduğu bu sebeple iyi muhafaza edilmesi gerektiği anlaşılmıştır.
\end{abstract}

\section{Determination of Quality Properties and Mineral Matter Content of Plant Parts of Forage Pea and Forage Broad Bean}

Keywords
Crude ash,
Crude
protein,
Forage broad
bean,
Forage pea,
Macro-micro
element,
Plant parts

Keywords Crude ash protein Forage broad bean, Forage pea, element, Plant parts 


\section{GíRIŞ̧}

Baklagiller, Leguminosae (Fabaceae) familyasında yer alan dünya üzerindeki en geniş familyalardan birisidir. Rhizobium cinsi bakteriler yardımı ile havadaki elementer azotu toprağa bağlayarak yüksek yapılı bitkilerin kullanabileceği forma dönüştürebilme yeteneklerinden dolayı mera alanlarında, tarım arazilerinde ve ekim nöbeti sisteminde önemlidir. Ayrıca diğer bitki türleri arasında ayrıcalıklı yere sahiptir [1]. Baklagiller içerisinde yer alan yem bezelyesi ve yemlik bakla bitkileri genel olarak tek yıllık ve kışlık yetiştirilip, ilkbaharda yeşil ot amaciyla biçilerek ara ürün olarak değerlendirilmektedir. Ot ve tohum üretimi, otlatma, yeşil gübreleme ve silaj amacıyla yetiştirilmektedir. Bunun yanı sıra yem bezelyesi yalnız veya tahıllarla karışım halinde ekilebilmektedir [2]. Yemlik bakla ise özellikle misır ve buğday bitkisi için iyi bir ön bitki olabilmekte, fakat aynı tarlaya ekilebilmesi için en az dört yıl süre geçmektedir [3,4].

Baklagiller kaliteli kaba yem üretimi için önemli bir yer teşkil etmektedir. Kaliteli kaba yemler; geviş getiren küçük ve büyükbaş hayvanların rumen flora ve faunasının gelişimi için gerekli olan protein, yağ, mineral ve vitaminlerce zengin olması bakımından çok önemlidir [5]. İz mineraller canlının yaşam fonksiyonlarının yerine getirilmesi ve fizyolojik işleyişin sürekliliğinde son derece önemlidirler. İz mineraller; hücrelerin, hormonların ve vücut enzimlerinin esansiyel yapı taşlarıdır [6].

Yapılan birçok araștırmada hasat zamanları, kaba yemlerin kalite özelliklerini, beslenme değerlerini ve sindirilebilirliklerini etkilemiştir [7,8,9,10] Bitkinin kök, sap, yaprak ve çiçek organları arasında da sindirim değerleri farklı olmaktadır [11]. Bitkilerin gelişme durumlarına bağlı olarak besin elementleri de $(\mathrm{Cu}, \mathrm{Mn}$ ve $\mathrm{Zn}$ ) farklılık göstermektedir [12] Küçük ve ark. [13] tarafından yapılan çalışmada doğal meradan farklı gelişme dönemlerinde toplanan yem bitkilerinin makro ve mikro besin elementlerinin içeriğinin gelişme dönemi ve bitki türlerine göre farklılıklar olduğunu bildirmişlerdir.

Bu nedenle bu çalışma, yem bezelyesi ve yemlik bakla bitkisinin; bitki kısımlarının (tüm bitki, sap, yaprak ve dal) kalite özelliklerinin yanı sıra hayvanlar için zorunlu olan mineral madde içeriklerini ( $\mathrm{Al}, \mathrm{B}, \mathrm{Ca}, \mathrm{Cd}, \mathrm{Co}, \mathrm{Cu}$, $\mathrm{Fe}, \mathrm{K}, \mathrm{Mg}, \mathrm{Mn}, \mathrm{N}, \mathrm{Ni}, \mathrm{P}, \mathrm{Pb}$ ve $\mathrm{Zn}$ ) tespit etmek amacıyla gerçekleştirilmiştir.

\section{MATERYAL VE METOT}

Araştırma, 2017-2018 y1lında Kahramanmaraş Sütçü İmam Üniversitesi, Ziraat Fakültesi, Tarla Bitkileri Bölümüne ait araştırma ve uygulama alanında yürütülmüştür. Deneme alanının bulduğu bölge 568 metre rakıma sahiptir ve Türkiye'nin $37^{\circ} 36^{\prime}$ Kuzey enlemleri ve $46^{\circ} 56^{\prime}$ Doğu boylam dereceleri arasında yer almaktadır. Bölge Doğu Akdeniz Geçit Kuşağı iklim özelliğine sahip olmakla beraber, gece gündüz sıcaklık farkı az, yazları sıcak ve kurak, kışları 1lık ve yağışlı geçmektedir.
Tablo 1. Kahramanmaraş ili iklim verileri [14]

\begin{tabular}{lrrrrrr}
\hline & \multicolumn{2}{c}{ Yağış $(\mathrm{mm})$} & \multicolumn{2}{c}{ Sicaklık $\left({ }^{\circ} \mathrm{C}\right)$} & \multicolumn{2}{c}{ Nispi Nem $(\%)$} \\
\cline { 2 - 7 } AYLAR & 2017 & Uzun & 2017 & Uzun & 2017 & Uzun \\
Kasım & 2018 & \multicolumn{1}{c}{ Yıllar } & 2018 & Yıllar & 2018 & Yıllar \\
Aralık & 33,2 & 87,5 & 12,2 & 11,5 & 64,17 & 66,68 \\
Ocak & 116,6 & 8,8 & 6,8 & 68,97 & 79,85 \\
Şubat & 60,2 & 125,4 & 7,4 & 4,9 & 69,45 & 69,99 \\
Mart & 50,2 & 93,4 & 9,6 & 6,4 & 69,44 & 65,62 \\
Top./Ort. & 384,4 & 531,2 & 14,1 & 10,6 & 60,80 & 60,00 \\
\hline
\end{tabular}

Tablo 1'de görüldüğü gibi ekimin yapıldığı dönemde toplam yağış $384,4 \mathrm{~mm}$ olarak gerçekleşmiş ve uzun yıllar ortalamasına göre $146,8 \mathrm{~mm}$ daha az yağış söz konusu olmuştur. Yine Sicaklık ortalaması deneme yapıldığ1 dönemde ortalama $10,42{ }^{\circ} \mathrm{C}$, uzun y1llar ortalamasında ise $8,04{ }^{\circ} \mathrm{C}$ olarak gerçekleșmiş ve uzun yıllara göre $2,38{ }^{\circ} \mathrm{C}$ daha sicak olmuştur. Uzun yıllar ortalaması göre Kahramanmaraş'ta ortalama nispi nem $\%$ 68,42 olurken, 2017-2018 döneminde \% 66,57 olarak gerçekleşmiştir. Deneme alanından 0-30 cm'lik toprak örneğine göre deneme alanı killi bir yapıdadır. Topraktaki yarayışlı potasyum $\left(\mathrm{K}_{2} \mathrm{O}\right)\left(55,1 \mathrm{~kg} \mathrm{da}^{-1}\right)$ yüksek seviyede, yarayışlı fosfor $\left(\mathrm{P}_{2} \mathrm{O}_{5}\right)\left(2,48 \mathrm{~kg} \mathrm{da}^{-1}\right)$ çok az, topraktaki organik madde miktarı $(\% 1,58)$ az, kireç miktarı $(\% 6,09)$ orta ve $\mathrm{pH}$ değeri 7,71 olarak belirlenmiştir.

Denemede, yemlik bakla (Vicia faba var. minor L.) ve yem bezelyesi (Pisum arvense L.) olmak üzere 2 farklı bitki türü ve tüm bitki, yaprak, sap ve dal olmak üzere dört farklı muamele grubundan oluşmuştur. Tohumlar hayvancılık yapan çiftçilerden elde edilmiștir. Bakla tohumlar1 $20 \mathrm{~kg}$ da-1 ve yem bezelyesi tohumlar1 $12 \mathrm{~kg}$ da-1 esasına göre $20 \mathrm{~m} 2$ alanda elle ekimi yapılmıştır. Ekimle birlikte $3 \mathrm{~kg}$ da-1 azot uygulaması yapılmıştır. Bitki örnekleri tam çiçeklenme döneminde 23.03.2018 tarihinde hasat edilmiş ve tüm bitki, yaprak, sap ve dal olmak üzere 4 farklı şekilde paketlenmiştir. Kuru madde oranlar1 belirlendikten sonra, materyaller $1 \mathrm{~mm}$ elek çapındaki öğütme makinasında öğütülerek yapılacak analizler için paketlenerek hazır hale getirilmiştir. Yem materyallerin ham protein oranı ve ham kül AOAC [15] tarafından bildirilen yöntemlere göre yapılmıştır.

Bitkiye ait yaprak, sap, dal ve tüm bitki örnekleri, Jones ve Case [16] tarafindan açıklandığı şekilde mineral madde analizine hazırlanmıştır. Numuneler, Jones ve Case [16] tarafindan tanımlanan $\mathrm{HNO} 3$ ve $\mathrm{HClO} 4$ kullanılarak yapılan blok-parçalama prosedürü izlenerek yakılmış ve örneklere ait süzükler elde edilmiştir. Örnekleri $25 \mathrm{ml}$ hacme getirmek için saf su eklenmiştir. Berrak solüsyon Perkin Elmer 3110 Atomik Absorbsiyon Spektrofotometresi ve spektrofotometrede elementer (Al, Ca, Cd, Co, Cu, Fe, K, Mg, Mn, N, Ni, Pb ve $\mathrm{Zn}$ ) okumalar için hazır hale getirilmiştir. Kuo [17]'nun bildirdiği üzere, bitki ekstraktlarında P konsantrasyonu belirlenmesi vanadomolibdafosforik asit kullanılarak UV-VIS spektrofotometresi ile yapılmıştır. Bütün analizler 3 tekerrürlü olarak gerçekleştirilmiştir.

\section{1. İstatistiksel Analizler}

Araştırmada elde edilen sonuçlar; tesadüf bloklarında bölünmüş parseller deneme desenine kullanılarak SAS 
paket programı ile değerlendirilmiştir. Ortalamalar arasındaki farkın karşılaştırılmasında ise LSD testi kullanılmıştır.

\section{BULGULAR}

Kahramanmaraş koşullarında yürütülen çalışmada; yemlik bakla ve yemlik bezelye türlerinde dört farklı bitki kısımlarında incelenen özelliklerden; kuru madde oran1, ham protein oran1, ham kül oranı Tablo 2'de, alüminyum, bor, kalsiyum, kadmiyum, kobalt, bakır, demir, potasyum, magnezyum, mangan, azot, nikel, fosfor, kurşun ve çinko (Al, B, Ca, Cd, Co, Cr, Cu, Fe, $\mathrm{K}, \mathrm{Mg}, \mathrm{Mn}, \mathrm{N}, \mathrm{Ni}, \mathrm{P}, \mathrm{Pb}$ ve $\mathrm{Zn}$ ) içeriklerine ait ortalama değerler Tablo 3'de gösterilmiştir.

Tür, tür x bitki kısımları interaksiyonu kuru madde oranı, ham protein oranı ve ham kül oranı üzerine etkisi çok önemli $(\mathrm{P} \leq 0,01)$ olmuştur. En yüksek kuru madde oranı yemlik bezelyede \% 21,06 oranında tespit edilmiştir. İnteraksiyon incelendiğinde en yüksek kuru madde oranı bitkinin yaprak kısmında \% 23,29 olarak saptanmıştır. Çalışmada ham protein oranlarına ait ortalama değerler incelendiğinde en yüksek değer yemlik bezelye bitkisinde \% 13,99 oranında tespit edilmiştir. Tür x bitki kısımları interaksiyon değerlerine göre en yüksek oran yaprak kısmında \% 19,57 olarak saptanmıştır. Bu oranı $\%$ 13,50 tüm bitki, \% 11,53 dal ve \% 7,85 oranında bitkisinin sap kısmı izlemiştir. Ham kül oranı türler arasında en yüksek bakla bitkisinde $(\%$ 16,43), interaksiyonda ise bitkinin yaprak k1sminda (\% 20,91) saptanmıştır. Bezelye bitkisine ait çalışmalar incelendiğinde; tüm bitkide, Uzun ve ark. [18] ham protein oranını \% 19,9, Koçer ve Albayrak [19] ham protein oranını \% 16,08, Canbolat ve ark. [20], ham protein oranını \% 17,84, ham kül oranını ise \% 5,74 olduğunu rapor etmişlerdir.

Çalışmada; en yüksek kuru madde, ham protein ve ham kül oranı bitkinin yaprak kısmında ve en yüksek kuru madde oranı ve protein oranı yemlik bezelyede bitkisinde, en yüksek kül oranı ise yemlik baklada tespit edilmiştir. Jung ve ark. [21], yem bitkilerde bulunan yaprakların saplara oranla yüksek ham protein ve daha düşük oranlarda ham selüloz içerdiğini bildirmektedirler. Bununla beraber protein içeriği bitkinin olgunlaşmasıyla birlikte bitkideki yaprak/sap oranının azalması, selüloz miktarında meydana gelen artış ham protein oranını düşürdüğü ifade edilmektedir [24]. Açıkgöz [22], hayvanların beslenme davranışlarında; yaprak oranı yüksek bitkileri tercih ettiklerini ve yeşil-kuru ot bol olarak verildiğinde, hayvanların öncelikle yaprakları tükettiğini bildirmiştir. $\mathrm{Bu}$ durum yaprakların saplara göre daha lezzetli olması ile açıklanabilir. Ayrıca kuru madde oranları, kül oranları ve protein oranları türler arasında farklılı olmasının bitkinin genetik yapısı, sicaklık ve gübrelemeye göre değiştiği rapor edilmektedir [23].
Tablo 2. Yemlik bezelye ve yemlik bakla bitki kısımlarının kuru madde, ham protein ve ham kül oranları

\begin{tabular}{|c|c|c|c|c|c|}
\hline \multirow{2}{*}{ Bitki Türleri } & \multicolumn{4}{|c|}{ Bitki Kısımları } & \multirow{2}{*}{ Ortalama } \\
\hline & Tüm Bitki & Yaprak & Sap & Dal & \\
\hline \multicolumn{5}{|c|}{ Kuru Madde Oranı (\%) } & $* *$ \\
\hline Y. Bakla & 16,66 & 20,54 & 15,18 & 16,12 & $17,13^{\mathrm{b}}$ \\
\hline Y. Bezelye & 18,61 & 26,02 & 19,65 & 19,94 & $21,06^{\mathrm{a}}$ \\
\hline Ortalama** & $17,64^{b}$ & $23,29^{\mathrm{a}}$ & $17,42^{b}$ & $18,03^{\mathrm{b}}$ & \\
\hline \multicolumn{5}{|c|}{ Ham Protein Oranı $(\%)$} & *** \\
\hline Y. Bakla & 12,90 & 18,28 & 6,41 & 11,36 & $12,24^{b}$ \\
\hline Y. Bezelye & 14,10 & 20,96 & 9,30 & 11,70 & $13,99^{\mathrm{a}}$ \\
\hline Ortalama** & $13,50^{b}$ & $19,57^{\mathrm{a}}$ & $7,85^{d}$ & $11,53^{\mathrm{c}}$ & \\
\hline \multicolumn{5}{|c|}{ Ham Kül Oranı (\%) } & $* *$ \\
\hline Y. Bakla & 13,93 & 23,13 & 12,65 & 16,03 & $16,43^{\mathrm{a}}$ \\
\hline Y. Bezelye & 12,67 & 18,68 & 12,30 & 10,34 & $13,49^{b}$ \\
\hline Ortalama** & $13,30^{\mathrm{b}}$ & $20,91^{\mathrm{a}}$ & $12,48^{b}$ & $13,18^{b}$ & \\
\hline
\end{tabular}

Araştırmada $\mathrm{Al}$ ve $\mathrm{B}$ verileri incelendiğinde; tür ve tür $\mathrm{x}$ bitki kısımları arasında oluşan farklılığın çok önemli olduğu saptanmıştır $(\mathrm{P} \leq 0,01)$. En yüksek $\mathrm{Al}$ ve $\mathrm{B}$ yemlik bakla bitkisinde (294 ve 16,1 ppm) tespit edilmiştir. Al en yüksek bitkinin yaprak kısmında (251 ppm), B ise bitkinin sap (15,7 ppm) kısmında tespit edilmiştir (Tablo 3). Hayvan beslemede iz mineraller ve önemi kapsamında bor elementi endokrin sistem, immun sistem ve beyinde de önemli işlevlere etki etmektedir [25]. Gürsoy ve Macit [26], bazı baklagil yem bitkilerinde B miktarının 5,91-40,39 ppm arasında değiştiğini bildirmiştir. Bulgularımız Gürsoy ve Macit [26] tarafından bildirilen B değerleri ile uyumludur.

Ca makro besin elementi ortalama değerleri incelendiğinde çalışmada türler arasında bir fark görülmezken, tür $\mathrm{x}$ bitki kısımları interaksiyonunda oluşan farkl1lık önemli düzeydedir $(\mathrm{P} \leq 0,01)$. Bitkide en fazla Ca tüm bitki, yaprak ve sap kısımlarında olmuştur. Çalışmada kalsiyum değeri tür $\mathrm{x}$ bitki kısımları interaksiyonuna göre 6019-7681 ppm arasında değişmiştir (Tablo 3). Ca hayvanların fizyolojik yaşamları için çok önemlidir. Noksanlığında; süt verimi ve doğurganlık oranında azalma görülmektedir [27]. Tajeda ve ark. [28], ruminant beslemesi için yem bitkilerinde en az 3,0 $\mathrm{g} \mathrm{kg}^{-1} \mathrm{Ca}$ bulunması gerektiğini rapor etmiştir. Kidambi ve ark. [29], kaba yemlerde bulunması gereken $\mathrm{Ca}$ değerinin $\% \quad 0,31$ olduğunu bildirmiştir. NRC [30], yonca için Ca değerinin \% 0,31 olduğu bildirmiştir. Vosiljevic ve ark. [31], macar fiğinin yaprak, sap ve meyvesinde $\mathrm{Ca}$ içeriklerinin farklı olduğunu ve içeriklerin sırasıyla 3507-867-1680 mg 100 $\mathrm{g}^{-1}$ olarak bildirmişlerdir. Gürsoy ve Macit [26], Ca içeriğinin baklagil türlerine göre \% 0,56-1,61 oranlar1 arasında değiştiğini saptamışlardır.

$\mathrm{Cd}$ ile ilgili ortalama değerler incelendiğinde $\mathrm{Cd}$ değerinin tür ve tür $\mathrm{x}$ bitki kısımları interaksiyonu arasında bir fark olmadığı gözlemlenmektedir. Co ve $\mathrm{Cr}$ değeri incelendiğinde tür, tür $\mathrm{x}$ bitki kısımları interaksiyonu arasında oluşan farkın önemli düzeyde olduğu görülmektedir $(\mathrm{P} \leq 0,01)$. Ortalama değerler incelendiğinde Co değeri en yüksek yemlik bakla $(0,46$ ppm) bitkisinin yaprak kısmında (0,34 ppm) saptanmıştır (Tablo 3). Co ruminant hayvanların zorunlu alması gereken iz elementler içerisinde yer almakta, vitamin B12 olarak tanımlanmaktadır. Vitamin B12 rumen sentezi için gereklidir [32]. Bitkilerde Co miktarı 0,0- 
0,07 ppm $\mathrm{kg}^{-1}$ seviyesinden daha düşük olduğu durumlarda ruminantlarda noksanlık belirtileri ortaya çıktığı bildirilmiştir [33]. Noksanlık belirtileri; iştahsızlık, kilo kaybı, süt veriminde azalma ve anemi ortaya çıkmaktadır [32]. Co için toksik düzey ise $10 \mathrm{ppm}$ olarak bildirilmiştir [30]. En yüksek $\mathrm{Cr}$ değeri ise yemlik baklada $(2,18 \mathrm{ppm})$; yaprak, sap ve dal k1smında $(1,69$ ppm) gözlemlenmiştir.

Çalışmada en yüksek $\mathrm{Cu}$ değeri yemlik bakla bitkisinde (10,22 ppm), yaprak kısmında $(9,87 \mathrm{ppm})$ saptanmıştır $(\mathrm{P} \leq 0,05 ; \mathrm{P} \leq 0,01)$. Bu ortalama değeri tüm bitki $(8,64$ ppm) , sap (7,84 ppm) ve bitkinin dal kısmı (6,99 ppm) izlemiştir (Tablo 3). Ruminant hayvanlar için $\mathrm{Cu}$ çok önemlidir. Eksikliğinde; kıl ve yapağı yapısında bozukluk, büyüme geriliği, anemi, diyare, eklem bozuklukları ve fertilite bozukluklarına yol açmaktadır [34]. Baklagil yem bitkilerinde Cu içeriği \% 6-13 [35] ve 2,22-12,36 ppm [26] olarak değiştiği rapor edilmiştir. Araştırmada, En yüksek Fe içeriği yemlik baklada yaprak kısmında saptanmıştır. Bitkinin diğer kısımları arasında önemli bir fark gözlenmemektedir $(\mathrm{P} \leq 0,01)$. Ortalama Fe içeriği türlere göre 118,2-249,7 ppm arasında, tür $\mathrm{x}$ bitki kısımları interaksiyonlarına göre 164,0-221,9 ppm arasında değiştiği tespit edilmiştir (Tablo 3). Fe hemoglobin yapısında görev almaktadır ve gebe olan hayvanlar demire fazla ihtiyaç duymaktadır. Noksanlığında; anemi, iştahsızlık ve buna bağlı olarak canlı ağırlık kaybı ortaya çıkabilmektedir. NRC [30], sığırların ihtiyacı olan Fe değerini 50 ppm olarak bildirmiştir. Baklagil yem bitkilerinde $\mathrm{Fe}$ içeriğini \% 109-145 [35], 105,9-893,7 ppm [26] arasında değiştiği bildirilmiştir.

$\mathrm{K}$ ve $\mathrm{Mg}$ değerlerinde türler arasında bir fark bulunmazken, tür $\mathrm{x}$ bitki kısımları interaksiyonlarında önemli fark gözlenmiştir $(\mathrm{P} \leq 0,01)$. Tablo 3 incelendiğinde en yüksek $\mathrm{K}$ değerleri sırasıyla tüm bitki (16616 ppm), sap (16461 ppm) ve dal kisminda (15953 ppm), en düşük K değeri ise yaprak kısmında (14163 ppm) saptanmıştır. Ortalama değerlere göre; en yüksek Mg değeri tüm bitki (3526 ppm) kısmında saptanmıştır. $\mathrm{Bu}$ değeri 3257 ppm ile yaprak kısmı izlemiştir. NRC [30] tarafindan sığırların beslemesi için \% $0,65 \mathrm{~K}$ ve \% $0,04 \mathrm{Mg}$ gereksinim olduğunu bildirmiştir. Gürsoy ve Macit [26], baklagil türlerinde $\mathrm{K}$ içeriğinin \% 0,70-2,69 ve $\mathrm{Mg}$ içeriğinin \% $0,11-0,51$ arasında değiştiğini bildirmiştir.

Mn hayvanlarda kemik gelişiminde rol oynamaktadır. Noksanlıkta; üreme ve iskelet sisteminde bozukluklar meydana gelmektedir [26]. Canlı ağırlığ $50 \mathrm{~kg}$ olan bir koyunun günlük 20-40 ppm Mn ihtiyaç duyduğu belirtilmiştir [36]. Gürsoy ve Macit [26], baklagil çeşitlerinde $\mathrm{Mn}$ içeriğinin 18,18-66,58 ppm arasında değiştiğini bildirmiştir. Araştırmamızda Mn içeriği türler incelendiğinde en yüksek yemlik bakla bitkisinde 26,17 ppm, tür $\mathrm{x}$ bitki kısımları interaksiyon incelendiğinde $27,55 \mathrm{ppm}$ ile yaprak kısmında saptanmıştır $(\mathrm{P} \leq 0,01)$. Tablo 3 tür ve tür $\mathrm{x}$ bitki kısımları interaksiyonunun $\mathrm{Na}$ üzerine etkisinin çok önemli olduğu gözlenmektedir. En yüksek değerler türler arasında yemlik bakla bitkisinde (8289 ppm), tür $\mathrm{x}$ bitki kısımları interaksiyon ortalamasında tüm bitki ve bitkinin dal kısmında (6723 ppm) saptanmıştır. Barnes [37], sığırlar için Na içeriğinin \% $\quad 0,06-01$ arasında olması gerektiğini bildirmiştir. NRC [38], koyun ve keçiler için kuru maddede \% 0,1-0,08 $\mathrm{Na}$ içeriğinin olması gerektiğini rapor etmiştir.

$\mathrm{Ni}$, ruminantlar için hem gerekli hem de toksik olduğu bilinmektedir. Ni üreazın bir bileşenidir ve ruminantların rumeninde meydana gelen birkaç bakteri türü için de gerekli olmaktadır. $0,1 \mathrm{mg} \mathrm{kg}^{-1}$ kuru maddenin altındaki miktarlarda $\mathrm{Ni}$ eksikliği semptomlarına yol açtığ bildirilmiştir [39]. Hayvanlarda nikel eksikliği düşük üreme oranları, glikoz ve lipit metabolizmasındaki değişiklikler ile ilişkilendirilirken, nikel toksisitesi embriyo-toksik ve kanserojen etkilere sebep olduğu bildirilmiştir [40]. Çalışmamızda ortalama değerler incelendiğinde en yüksek $\mathrm{Ni}$ seviyesi yemlik bakla bitkisinde $(8,12 \mathrm{ppm})$, tüm bitki $(8,77 \mathrm{ppm})$ tespit edilmiştir (Tablo 3). P, hayvan vücudunda kalsiyumdan sonra en yüksek miktarda bulunan bir makro elementtir. $\mathrm{P}$, iskeletin büyümesinde, diş gelişimi, kanın kimyasal yapısında, vücudun asit-baz dengesinde vitamin enzim aktivitelerinde çok önemli rol oynar. $\mathrm{P}$ bitkilerde \% 0,02-0,08 arasinda olup fosforca eksik topraklarda yetişen bitkilerde bu miktardan daha az bulunur [41]. Sığırların beslenmesi için ise \% 0,23 P gerekli olduğu bildirilmiştir [30]. Gürsoy ve Macit [26], baklagil çeşitlerine göre $\mathrm{P}$ içeriğinin \% $1,16-1,28$ oranında değiştiğini rapor etmişlerdir. Araştırmamızda P miktarında türler arasında önemli $(\mathrm{P} \leq 0,05)$, tür $\mathrm{x}$ bitki kısımları arasında çok önemli bir fark gözlenmektedir $(\mathrm{P} \leq 0,01)$. $\mathrm{P}$ miktarı; en yüksek yemlik bakla bitkisinde (3173 ppm), yaprak (3428 ppm) ve tüm bitki olarak incelediğimiz ölçümlerde saptanmıştır. En az P içeriği bitkilerin dal kısmından elde edilmiştir (Tablo 3).

Çalışmamızda $\mathrm{Pb}$ miktarı türler ve tür x bitki kısımları interaksiyon varyans analiz sonucuna göre önemli çıkmamıştır. Araştırmada $\mathrm{Pb}$ değeri 1,19-1,37 ppm arasında değişmiştir (Tablo 3). Tarım ve Orman Bakanlığı'nın kaba yemlerde $\mathrm{Pb}$ üst sınır miktarı 30 ppm olarak rapor etmiştir [42]. Yemlik bakla ve yemlik bezelye $\mathrm{Pb}$ değerleri, Bakanlık tarafından bildirilen değerin altında çıkmıştır. Zn, hücre solunumu, ikincil oksijen kullanımı, DNA ve RNA, hücre zarının bütünlüğü, serbest radikallerin uzaklaştırılması, canlıların büyüme ve gelişmesinde, immun sisteminde görev yapan bir iz mineraldir [43]. Barnes [37], sığırlar için Zn gereksinimin 20-40 ppm olması gerektiğini bildirmiştir. NRC [30], ise Ruminantlar da Zn gereksinimi 18-73 ppm ve ortalama olarak $40 \mathrm{ppm}$ olduğu belirtmiştir. Gürsoy ve Macit [26], baklagil bitkilerinde $\mathrm{Zn}$ çeşitlere göre 14,11-195 ppm arasında değiştiğini bildirmiştir. Çalışmada ortalama $\mathrm{Zn}$ içeriği en yüksek yemlik bezelye bitkisinde 16,84 ppm $(\mathrm{P} \leq 0.05)$, yaprak kısmında 18,93 ppm olarak tespit edilmiştir (Tablo 3). Tüm bitki değerleri ele alındığında; yemlik bezelye 22,58 ppm Zn içeriği ile NRC [30] ve Gürsoy ve Macit [26] tarafından bildirilen değer ile uyumlu bulunmuştur. 
Tablo 3. Yemlik bezelye ve yemlik bakla bitki kısımlarının makromikro besin elementi içeriklerine etkisi (ppm)

\begin{tabular}{|c|c|c|c|c|c|}
\hline \multirow{2}{*}{ Bitki Türleri } & \multicolumn{4}{|c|}{ Bitki Kısımları } & \multirow{2}{*}{ Ortalama } \\
\hline & Tüm Bitki & Yaprak & Sap & Dal & \\
\hline \multicolumn{5}{|c|}{$\mathrm{Al}$} & *** \\
\hline Y. Bakla & 171 & 393 & 277 & 334 & $294^{\mathrm{a}}$ \\
\hline Y. Bezelye & 152 & 109 & 78 & 72 & $103^{b}$ \\
\hline Ortalama** $^{* *}$ & $161^{\mathrm{c}}$ & $251^{\mathrm{a}}$ & $178^{\mathrm{c}}$ & $203^{b}$ & \\
\hline \multicolumn{5}{|c|}{ B } & ** \\
\hline Y. Bakla & 15,1 & 14,6 & 19,7 & 15,0 & $16,1^{\mathrm{a}}$ \\
\hline Y. Bezelye & 13,0 & 12,0 & 11,7 & 11,3 & $11,9^{b}$ \\
\hline Ortalama** & $14,0^{b}$ & $13,3^{b}$ & $15,7^{\mathrm{a}}$ & $13,1^{\mathrm{b}}$ & \\
\hline \multicolumn{5}{|c|}{$\mathrm{Ca}$} & öd \\
\hline Y. Bakla & 4905 & 7184 & 8354 & 6633 & 6769 \\
\hline Y. Bezelye & 10457 & 7134 & 5441 & 5404 & 7109 \\
\hline Ortalama** & $7681^{a}$ & $7159^{a}$ & $6897^{\mathrm{a}}$ & $6019^{b}$ & \\
\hline \multicolumn{5}{|c|}{$\mathrm{Cd}$} & öd \\
\hline Y. Bakla & 0,01 & 0,01 & 0,01 & 0,02 & 0,01 \\
\hline Y. Bezelye & 0,01 & 0,02 & 0,01 & 0,03 & 0,10 \\
\hline Ortalama** & 0,01 & 0,01 & 0,01 & 0,02 & \\
\hline \multicolumn{5}{|c|}{ Co } & $* *$ \\
\hline Y. Bakla & 0,32 & 0,60 & 0,42 & 0,49 & $0,46^{\mathrm{a}}$ \\
\hline Y. Bezelye & 0,13 & 0,09 & 0,06 & 0,06 & $0,08^{b}$ \\
\hline Ortalama** & $0,23^{b}$ & $0,34^{\mathrm{a}}$ & $0,24^{b}$ & $0,28^{\text {ba }}$ & \\
\hline \multicolumn{5}{|c|}{$\mathrm{Cr}$} & *** \\
\hline Y. Bakla & 1,41 & 2,43 & 2,45 & 2,42 & $2,18^{\mathrm{a}}$ \\
\hline Y. Bezelye & 1,21 & 0,95 & 0,94 & 0,84 & $0,98^{b}$ \\
\hline Ortalama** & $1,31^{\mathrm{b}}$ & $1,69^{\mathrm{a}}$ & $1,69^{\mathrm{a}}$ & $1,63^{\mathrm{a}}$ & \\
\hline \multicolumn{5}{|c|}{$\mathrm{Cu}$} & $*$ \\
\hline Y. Bakla & 8,52 & 11,87 & 10,10 & 10,38 & $10,22^{a}$ \\
\hline Y. Bezelye & 8,78 & 8,10 & 5,58 & 3,59 & $6,51^{\mathrm{b}}$ \\
\hline Ortalama** & $8,64^{\text {ba }}$ & $9,87^{\mathrm{a}}$ & $7,84^{\text {ba }}$ & $6,99^{b}$ & \\
\hline \multicolumn{5}{|c|}{$\mathrm{Fe}$} & $* *$ \\
\hline Y. Bakla & 162,6 & 327,0 & 222,2 & 287,1 & $249,7^{\mathrm{a}}$ \\
\hline Y. Bezelye & 173,1 & 116,9 & 105,8 & 76,9 & $118,2^{b}$ \\
\hline Ortalama** & $167,9^{b}$ & $221,9^{\mathrm{a}}$ & $164,0^{b}$ & $182,0^{\mathrm{b}}$ & \\
\hline \multicolumn{5}{|c|}{$\mathrm{K}$} & öd \\
\hline Y. Bakla & 16550 & 13051 & 19118 & 15171 & 15972,3 \\
\hline Y. Bezelye & 16681 & 15276 & 13804 & 16735 & 15624,0 \\
\hline Ortalama** & $16616^{\mathrm{a}}$ & $14163^{b}$ & $16461^{\mathrm{a}}$ & $15953^{a}$ & \\
\hline \multicolumn{5}{|c|}{$\mathrm{Mg}$} & öd \\
\hline Y. Bakla & 2089 & 3274 & 4034 & 2589 & 2996 \\
\hline Y. Bezelye & 4965 & 3239 & 2133 & 2488 & 3206 \\
\hline Ortalama** & $3526^{a}$ & $3257^{\text {ba }}$ & $3084^{b}$ & $2538^{c}$ & \\
\hline & & Mn & & & $* *$ \\
\hline Y. Bakla & 14,45 & 39,09 & 23,10 & 28,04 & $26,17^{\mathrm{a}}$ \\
\hline Y. Bezelye & 28,77 & 16,02 & 10,13 & 9,91 & $16,21^{b}$ \\
\hline Ortalama** & $21,60^{b}$ & $27,55^{a}$ & $16,61^{\mathrm{c}}$ & $18,97^{\mathrm{cb}}$ & \\
\hline & & $\mathrm{Na}$ & & & $* *$ \\
\hline Y. Bakla & 12302 & 3679 & 9831 & 7345 & $8289^{a}$ \\
\hline Y. Bezelye & 1143 & 1292 & 971 & 1658 & $1266^{b}$ \\
\hline Ortalama** & $6723^{a}$ & $2486^{d}$ & $5401^{b}$ & $6723^{a}$ & \\
\hline & & $\mathrm{Ni}$ & & & $* *$ \\
\hline Y. Bakla & 14,07 & 6,20 & 7,93 & 4,28 & $8,12^{\mathrm{a}}$ \\
\hline Y. Bezelye & 3,48 & 3,14 & 7,95 & 2,07 & $4,16^{b}$ \\
\hline Ortalama** & $8,77^{\mathrm{a}}$ & $4,67^{\mathrm{c}}$ & $7,94^{b}$ & $3,17^{d}$ & \\
\hline & & $\mathrm{P}$ & & & $*$ \\
\hline Y. Bakla & 2630 & 3615 & 3435 & 3013 & $3173^{a}$ \\
\hline Y. Bezelye & 4183 & 3240 & 2389 & 2120 & $2983^{b}$ \\
\hline Ortalama** & $3406^{a}$ & $3428^{a}$ & $2912^{b}$ & $2567^{\mathrm{c}}$ & \\
\hline & & $\mathrm{Pb}$ & & & öd \\
\hline Y. Bakla & 1,36 & 1,24 & 1,41 & 0,76 & 1,19 \\
\hline Y. Bezelye & 1,14 & 1,23 & 1,14 & 1,97 & 1,37 \\
\hline Ortalama** & 1,25 & 1,23 & 1,28 & 1,37 & \\
\hline & & $\mathrm{Zn}$ & & & $*$ \\
\hline Y. Bakla & 11,03 & 20,53 & 15,48 & 16,20 & $15,81^{b}$ \\
\hline Y. Bezelye & 22,58 & 17,33 & 13,16 & 14,31 & $16,84^{\mathrm{a}}$ \\
\hline Ortalama** & $16,80^{b}$ & $18,93^{a}$ & $14,31^{\mathrm{c}}$ & $15,25^{\mathrm{c}}$ & \\
\hline
\end{tabular}

** $\mathrm{P} \leq 0,01$ önemli, $* \mathrm{P} \leq 0,05$ önemli, öd: önemli değil.

\section{SONUÇ}

Yem bitkisi olarak hayvan beslemede kullanılan yemlik bakla ve yemlik bezelyenin kimyasal özellikleri ve makro ve mikro mineral içeriklerini tespit etmek için yapılan bu araştırma, baklagil yem bitkilerinin kendi aralarında ve bu bitkilere ait farklı bitki kısımlarında kalite ve mineral madde içeriği yönünden önemli farklılıkların olduğunu ortaya koymuştur. Araştırmada, kuru madde oranı ve ham protein oranı bakımından yemlik bezelyenin yemlik bakladan daha üstün olduğu buna karşılık ham kül oranı bakımından yemlik baklanın yemlik bezelyeden daha üstün olduğu görülmüştür. Bitkilerinin farklı kısımlarının makro ve mikro element içerikleri bakımından detaylı araştırmalar yapılmadığı anlaşılmaktadır. Özellikle bitkilerde fotosentezin ana merkezi olan yaprağın diğer bitki kısımlarına göre çok önemli fonksiyonları ve özellikleri olduğu görülmektedir. Bitkilerin kimyasal özellikleri açısından yaprağın diğer kısımlara göre ciddi bir üstünlük gösterdiği, yine yaprağın diğer bitki kısımlarına göre birçok elementi daha fazla oranda ihtiva ettiği görülmüştür. $\mathrm{Bu}$ sebeple hayvan beslemede kullanılan yem bitkilerinin özellikle yaprakları kurutulurken ve depolanırken iyi muhafaza edilmeli ve zayi olması engellenmelidir. Çalışmanın bu alanda yapılacak çalışmalara 1 şı tutacak bir kaynak olacağı düşünülmektedir.

\section{KAYNAKLAR}

[1] Tan M, Serin Y. Baklagil yem bitkilerinin tarımsal özellikleri, ekonomik önemleri, taksonomileri ve genel yapısal özellikleri. Yem bitkileri, cilt 2, 2009; 277-289.

[2] Açıköz E, Katkat AV, Ömeroğlu S, Okan B. Mineral elements and amino acid concentrations in field pea and common vetch herbages and seeds. Z. Acker-und Pflanzenbau (J. Agronomy \& Crop Science). 1985;155, 179-185.

[3] Geisler G. Pflanzenbau, Institutes Für Pflanzenbau Und Pflanzenzünchtung Der Christian- AlbrechtsUniversitat Kiel. 1987.

[4] Geren H, Avcioğlu R, Kavut YT. Yemlik bakla (Vicia faba var. minor L.) . Yem bitkileri, cilt 2, Bölüm 14, 2009;435-439.

[5] Alçiçek A, Karaayvaz K. Sı ğır besisinde mısır silajı kullanımı. Animalia. 2003; 20(3):18-76.

[6] Sarıbay MK, Özsoy B. Sütçü ineklerde bakır, çinko ve selenyumun fertilite açısından önemi. Bahri Dağdaş Hayvancılık Araştırma Dergisi. 2019; 8(1):36-45.

[7] Kaplan M, Kamalak A, Özkan ÇÖ, Atalay Aİ. Vejetasyon döneminin yabani korunga otunun potansiyel besleme değerine, metan üretimine ve kondense tanen içeriğine etkisi. Harran Üniversitesi Veteriner Fakültesi Dergisi. 2014; 3(1) 1-5.

[8] Kamalak A. Determination of potential nutritive value of Polygonum aviculare hay harvested at three maturity stages. J Appl Anim Sci. 2010; 38:69-71.

[9] Kamalak A, Atalay AI, Ozkan CO, Kaya K, Tatlyer A. Determination of nutritive value of 
Trigonella kotschi Fenz hay harvested at three different maturity stages. Kafkas Universitesi Veteriner Fakültesi Dergisi. 2011; 17(4):635-640.

[10] Üke Ö, Kale H, Kaplan M, Kamalak A. Olgunlaşma döneminin kinoa (Chenopodium quinoa Willd.)'da ot verimi ve kalitesi ile gaz ve metan üretimine etkisi. KSÜ Doğa Bilimleri Dergisi. 2017; 20(1):42-46.

[11] Van Soest PJ. Nutritional ecology of the ruminant ( $2^{\text {nd }}$ Ed.). Cornell Uni. press., Ithaca, N.Y., 1994; 7 21.

[12] Gralak MA, Bates DL, Von Keyserlingk MSG, Fisher LJ. Influence of species, cultivar and cut on the micro element content of grass forages. Slowak J Anim Sci. 2006; 39:84-88

[13] Küçük Ç, Cevheri C, Polat T, Avcı M. Şanlıurfa (Akabe mevki) doğal mera bitkilerinin besin elementleri içerikleri ve toprakların mikrobiyal biyomas $\mathrm{c}$, fungal ve bakteriyal biyomas $\mathrm{c}$ değerlerinin belirlenmesi. Harran Üniversitesi Vet. Fak. Dergisi. 2016; 5(2):129-134

[14] Anonim. Kahramanmaraş, Meteoroloji Genel İl Müdürlüğü. 2019.

[15] AOAC. Association of Official Analytical Chemists. Official Method of Analysis. 15th.ed. Washington, DC. USA. 1990. p. 66-88.

[16] Jones JJB, Case VW. Sampling, handling, and analyzing plant tissue samples, chapter 15. In R.L. Westerman (ed) Soil Testing and Plant Analysis, Third Edition, SSSA, Madison, Wisconsin, USA, 1990. P. 390-420.

[17] Kuo S. Phosphorus in D.L. Sparks (Ed) Methods of Soil Analysis, Part 3, Chemical Methods, SSSA Book Series Number 5, SSSA., Madison, WI, 1996; 869-921.

[18] Uzun A, Gün H, Açıkgöz E.. Farklı gelişme dönemlerinde biçilen bazı yem bezelyesi (Pisum sativum L.) çeşitlerinin verim ve kalite özellikleri. IX. Tarla Bitkileri Kongresi Çayır Mera ve Yem Bitkiler Cilt III. Bursa. 2011. p.1707- 1707

[19] Kocer A, Albayrak S. Determination of forage yield and quality of pea (Pisum sativum L.) mixtures with oat and barley. Turkish Journal of Field Crops. 2012; 17(1):96-99.

[20] Canbolat Ö, Kara H, Filya İ. Bazı baklagil kaba yemlerinin in vitro gaz üretimi, metabolik enerji, organik madde sindirimi ve mikrobiyal protein üretimlerinin karşılaştırılması. U. Ü. Ziraat Fakültesi Dergisi, 2013; 27(2):71-81

[21] Jung HG, Sheaffer CC, Barnes DK, Halgerson JL. Forage quality variation in the U.S. alfalfa core collection. Crop Science. 1997; 37:1361-1366.

[22] Açıkgöz E. Yem Bitkileri. (III. Baskı) Uludağ Üniv. Güçlendirme Vakıf Yayın No: 182. VIPAŞ AŞ. Yayın No: 58. Bursa. 2001

[23] Ball DM, Collins M, Lacefield GD, Martin NP, Mertens DA, Olson KE, Putnam DH, Undersander DJ, Wolf MW. Understanding Forage Quality. American Farm Bureau Federation Pub., Park Ridge, IL. 2001.

[24] Nesheim L. Herbage quality of Elytrica repens, Agrosti capillaris and Phalaris arundinacea. Soil Grassland. Animal Relationships in: Proc. 13th
General Meeting of the European Grassland Federation. 1990; 2:91-95

[25] Nielsen FH. Nutritional requirements for boron, silicon, vanadium, nickel and arsenic: current knowledge and speculation. Faseb J. 1991. 5:26612667.

[26] Gürsoy E, Macit M. Erzurum ili çayır ve meralarında doğal olarak yetişen bazı buğdaygil yem bitkilerinin nispi yem değerleri bakımından karşılaştırılması. YYÜ Tar Bil Der.2017; 27(3):309-317.

[27] Goff JP. Dry cow nutrition and metabolic disease in parturient cows. Proceeding Western Canadian Dairy Seminar Red Deer. 1999.

[28] Tajeda R, Mcdowell LR, Martin FG, Conrad JH. Mineral element analyses of various tropical forages in Guatemala and their relationship to soil concentrations. Nutrition Reports International. 1985; 32: 313-324

[29] Kidambi SP, Matches AG and Gricgs TC. Variability for $\mathrm{Ca}, \mathrm{Mg}, \mathrm{K}, \mathrm{Cu}, \mathrm{Zn}$, and $\mathrm{K} /(\mathrm{Ca}+\mathrm{Mg})$ ratio among 3 wheat grasses and sainfoin on the southern high plains. J. of Range Management. 1989; 42: 316-322.

[30] National Research Council (NRC). In: Nutrients requirement of dairy cattle, 7 th rev. ed. The National Academies Press, Washington D.C. 2001.

[31] Vosiljevic S, Milic D, Milic A. Chemical attibutes and quality improvement of forage legumes. Biotechnology in animal Husbandry. 2009; 25: 493-504.

[32] Stangl GI, Schwarz FJ, Kirchgessner M Moderate longterm cobalt deficiency affects liver, brain, and erythrocyte lipids and lipoprotein of cattle. Nutrition Research. 1999; 19 (3): 415-427.

[33] İmren HY, Şahal M Veteriner İç Hastalıkları Kitabı, Feryal Yayıncılık, Ankara, 1991.

[34] Spitzer JC. Influences of nutrition on reproduction in beef cattle. Current Therapy in Theriogenology. DA Morrow (editör). Bask1 2. W.B. Saunders, Toronto. 1986. p. 322-323.

[35] Zia Ul Haq M, Shahid SA, Ahmad S, Qayum M, Rasool N. Mineral Contents and Antioxidant Potential of Selected Legumes of Pakistan. J. of Medical Plants Research. 2012; 6(32):4735-4740.

[36] National Research Council (NRC). Nutrient requirement of Sheep. Sixth Revised Ed., , National Academy Press, Washington, D.C.1985. p. 1-99

[37] Barnes TG, Varner LW, Blankenship LH, Fillinger TJ, Heineman SC. Macro and trace mineral content of selected South Texas deer forages. Journal of Range Management. 1990; 43: 220-223.

[38] [38] National Research Council (NRC). Nutrient requirements of small ruminants: sheep, goats, cervids, nad new world camelids. National Research Council of the National Academies, Washington DC. 2007.

[39] Anke M, Angelow L, Glei M, Miiller M, Illing H. The biological importance of nickel in the food chain. Fresenius J Anal Chem. 1995; 352:92-96

[40] Samal L, Mishra C, Significance of nickel in livestock health and production. IJAVMS. 2011; 5(3):349-361. 
[41] Olgun H, Ünal S. Hayvan beslemede fosfor. Lalahan Zoo. Arş. Ens. Der. 1983; 23(1-2): 61-64.

[42] Resmi Gazete. Yemlerde istenmeyen maddeler hakkında tebliğde değişiklik yapılmasına dair tebliğ. Tarım ve Köyişleri Bakanlığı Koruma Kontrol Genel Müdürlüğü. Gazete Tarihi: 19.04.2014 Resmî Gazete Sayıs1: 28977.

[43] Fidancı UR. Yurdumuz hayvanlarında iz element noksanlıkları. Veteriner Hekimler Derneği Dergisi. 1986; 56(1):37-44. 